\title{
Sekam Padi untuk Menyerap Ion Logam Tembaga dan Timbal dalam Air Limbah
}

\author{
Nurhasni*, Hendrawati, Nubzah Saniyyah \\ Program Studi Kimia Fakultas Sains dan Teknologi UIN Syarif Hidayatullah Jakarta \\ *Email: hasni1806@gmail.com
}

\begin{abstract}
Abstrak
Penelitian ini bertujuan untuk memanfaatkan sekam padi sebagai penyerap ion logam tembaga dan timbal dalam air limbah telah dilakukan. Metode yang digunakan adalah metode statis (batch). Penentuan kondisi optimum meliputi massa adsorben, $\mathrm{pH}$, konsentrasi adsorbat dan lama pemanasan. Hasil analisis menggunakan Spektrofotometer Serapan Atom (AAS) menunjukkan efisiensi penyerapan tertinggi pada air limbah multikomponen mencapai $99.38 \%$ untuk ion logam $\mathrm{Pb}$. Analisis air limbah laboratorium kimia UIN Syarif Hidayatullah Jakarta, menunjukkan penyerapan tertinggi mencapai $78.57 \%$ untuk ion logam $\mathrm{Cu}$.
\end{abstract}

Kata kunci : sekam padi, adsorben ion logaam timbal, adsorben ion logam tembaga, air limbah

\begin{abstract}
This research aims to rice huskas absorbent of copper and lead metalions in the waste water. The method used is a static method (batch). Determination of optimum conditions includes adsorbent mass, $\mathrm{pH}$, absorbate concentration and duration of heating. The analysis using Atomic Absorption Spectrophotometer (AAS) showed the highest absorption efficiency of $\mathrm{Pb}$ metal ion in multicomponent wastewater reached $99,38 \%$. The analysis of wastewater from chemistry laboratorium UIN Syarif Hidayatullah Jakarta showed, the highest absorption of $\mathrm{Cu}$ metal ion was $78,57 \%$.
\end{abstract}

Keywords : rice husk, the metal ions cadmium, chromium metal ions, wastewater

\section{PENDAHULUAN}

Perkembangan dalam bidang industri di Indonesia pada saat ini cukup pesat. Hal ini ditandai dengan semakin banyaknya industri yang memproduksi berbagai jenis kebutuhan manusia seperti industri kertas, tekstil, penyamak kulit, dan sebagainya. Seiring dengan pertambahan industri tersebut, maka semakin banyak pula limbah (hasil sampingan yang diproduksi sebagai limbah). Salah satu limbah tersebut logam berat yang dibuang sebagai limbah. Logam yang dimaksud adalah timbal $(\mathrm{Pb})$, kromium $(\mathrm{Cr})$, kadmium $(\mathrm{Cd})$ dan tembaga $(\mathrm{Cu})$ Limbah ini akan menyebabkan pencemaran serius terhadap lingkungan jika kandungan logam berat yang terdapat di dalamnya melebihi ambang batas serta mempunyai sifat racun yang sangat berbahaya dan akan menyebabkan penyakit serius bagi manusia apabila terakumulasi di dalam tubuh.

Beberapa metode kimia maupun biologis telah dicoba untuk mengambil logam berat yang terdapat di dalam limbah, diantaranya adsorpsi, pertukaran ion (ion exchange), dan pemisahan dengan membran. Proses adsorpsi lebih banyak dipakai dalam industri karena mempunyai beberapa keuntungan, yaitu lebih ekonomis dan juga tidak menimbulkan efek samping yang beracun serta mampu menghilangkan bahanbahan organik (Setyaningtyas, 2005). Menurut Meludzinska (1999), adsorpsi adalah proses akumulasi adsorbat pada permukaan adsorben 
yang disebabkan oleh gaya tarik antar molekul adsorbat dengan permukaan adsorben. Interaksi yang terjadi pada molekul adsorbat dengan permukaan kemungkinan diikuti lebih dari satu interaksi, tergantung pada struktur kimia masing-masing komponen.

Kebanyakan adsorben yang digunakan dalam proses adsorpsi adalah alumina, karbon aktif, silika gel, dan zeolit. Adsorben tersebut mempunyai kemampuan adsorpsi yang baik tetapi tidak ekonomis. Dewasa ini sedang digalakkan penelitian mengenai penggunaan adsorben alternatif yang berasal dari alam, dimana selain memiliki kemampuan adsorpsi yang baik juga bersifat lebih ekonomis (Jalali et al., 2002).

Salah satu adsorben yang menjanjikan adalah limbah organik seperti limbah tanaman jagung, padi, pisang, dan lain-lain. Di antara beberapa limbah organik tersebut yang menarik adalah penggunaan sekam padi. Hal ini disebabkan sifat sekam padi yang rendah nilai gizinya, tahan terhadap pelapukan, memiliki kandungan abu yang tinggi, bersifat abrasif, menyerupai kandungan kayu, serta memiliki kandungan karbon yang cukup tinggi (Danarto, 2007).

Negara-negara agraris umumnya mempunyai masalah terhadap limbah hasil pertanian karena terbatasnya tempat penumpukan atau tempat pembuangan hasil sampingan tersebut. Hal ini berkaitan dengan ketersediaan limbah sekam padi yang cukup banyak di segala tempat di sekitar penggilingan padi dan pemanfaatan limbah tersebut yang masih terbatas. Bahkan sekam padi merupakan limbah pertanian yang menjadikan beban bagi petani.

Pada negara-negara agraris yang telah maju teknologinya, limbah padi ini hampir tidak menjadi masalah bagi lingkungan karena telah dapat dimanfaatkan, antara lain dalam bidang sumber energi, bahan bangunan, industri kimia, pakan ternak, sumber karbon, dan lain-lain.

Dewasa ini keberadaan abu sekam padi di Indonesia belum mendapatkan perhatian, dan hanya terbatas untuk beberapa keperluan sederhana misalnya untuk abu gosok. Bahkan di beberapa daerah sekam padi dibuang dan dianggap sebagai bahan yang kurang bermanfaat. Padahal, abu sekam padi merupakan bahan yang sangat potensial sebagai bahan penyerap logam berat dalam air. Abu sekam padi dapat digunakan sebagai adsorben karena selain merupakan material berpori juga mempunyai gugus aktif yaitu $\mathrm{Si}-\mathrm{O}-\mathrm{Si}$ dan $\mathrm{Si}-\mathrm{OH}$ (Setyaningtyas, 2005).

Tujuan penelitian ini adalah untuk mengetahui daya serap ion logam timbal dan tembaga oleh sekam padi sehingga sekam padi dapat dimanfaatkan sebagai salah satu adsorben.

\section{METODE PENELITIAN}

\section{Tempat dan Waktu Penelitian}

Penelitian ini dilaksanakan selama 3 bulan. Preparasi sampel serta analisis parameter fisik dan kimia dilakukan di Laboratorium Kimia, sedangkan uji kuantitatif ion logam dilakukan di Laboratorium Lingkungan, Pusat Laboratorium Terpadu (PLT) Universitas Islam Negeri Syarif Hidayatullah Jakarta.

\section{Alat dan Bahan}

Spektroskopi Serapan Atom Analyst 700 (Perkin Elmer), Pengayak listrik, Neraca Analitik, pH meter, oven listrik, shaker batch, glass wool, kertas saring dan peralatan gelas lainnya.

Bahan yang digunakan dalam penelitian ini adalah $\mathrm{NaOH}, \mathrm{Pb}\left(\mathrm{NO}_{3}\right)_{2}, \mathrm{CuSO}_{4} .5 \mathrm{H}_{2} \mathrm{O}, \mathrm{HNO}_{3}$ (p.a),larutan buffer, aquadest dan sekam padi (yang didapatkan dari penggilingan padi di Kampung Jati, Tangerang).

\section{Prosedur Penelitian}

Penelitian dilaksanakan dalam tiga tahap. Pertama adalah pembuatan adsorben dari arang sekam padi. Kedua adalah pengujian kemampuan penyerapan ion logam $\mathrm{Cu}$ dan $\mathrm{Pb}$ oleh arang sekam padi dengan variasi massa arang sekam padi, variasi konsentrasi larutan ion logam, variasi $\mathrm{pH}$, serta variasi lama pemanasan untuk mengetahui kondisi optimum dengan menggunakan metode sorpsi batch. Ketiga adalah mengaplikasikannya dengan menggunakan limbah multikomponen dan limbah yang berasal dari PLT UIN Syarif Hidayatullah Jakarta yang didasarkan pada kondisi optimum yang dihasilkan dari tahap sebelumnya. 


\section{Pembuatan Adsorben dari Sekam Padi}

Sekam padi dicuci dengan air sampai bersih dan dijemur di bawah terik matahari hingga kering. Lalu sekam padi yang telah bersih tersebut diarangkan pada suhu $250{ }^{\circ} \mathrm{C}$ selama 2.5 jam. Kemudian dihaluskan dan diayak dengan ukuran $212 \mathrm{~m}$. Lalu arang yang dihasilkan disimpan untuk digunakan dalam proses adsorpsi logam berat.

\section{Penentuan Kondisi Optimum Penyerapan}

a. Pengaruh Massa Sekam Padi Terhadap Penyerapan Ion Logam $\mathbf{C u}$ dan $\mathbf{P b}$

Adsorben dengan ukuran partikel $212 \mathrm{~m}$ ditimbang masing-masing 0,$5 ; 1,0 ;$ dan 1,5 gram. Lalu ditambahkan larutan ion logam sebanyak $10 \mathrm{~mL}$ dengan konsentrasi 20 ppm dan dishaker selama 30 menit dengan kecepatan putaran $180 \mathrm{rpm}$. Setelah itu disaring dan filtrat yang dihasilkan ditampung dan ditepatkan volumenya $10 \mathrm{~mL}$ dengan aquadest, ditambah 1 tetes asam nitrat dan diukur dengan SSA.

\section{b. Pengaruh Konsentrasi Ion Logam Terhadap Penyerapan Ion Logam Cu dan Pb}

Adsorben dengan ukuran partikel212 m ditimbang masing-masing 0.5 gram, lalu ditambahkan larutan ion logam sebanyak $10 \mathrm{~mL}$ dengan variasi konsentrasi 20, 40, 60, 80, dan 100 ppm. Kemudian dishaker selama 30 menit dengan kecepatan putaran $180 \mathrm{rpm}$. Setelah itu disaring dan filtrat yang dihasilkan ditampung dan ditepatkan volumenya $10 \mathrm{~mL}$ dengan aquadest, ditambah 1 tetes asam nitrat dan diukur dengan SSA.

\section{c. Pengaruh pH Ion Logam Terhadap Penyerapan Ion Logam $\mathbf{C u}$ dan $\mathbf{P b}$}

Adsorben dengan ukuran partikel $212 \mathrm{~m}$ ditimbang masing-masing 0.5 gram, lalu ditambahkan $10 \mathrm{~mL}$ larutan ion logam dengan konsentrasi 20 ppm dengan variasi $\mathrm{pH} \mathrm{3,} \mathrm{4,} \mathrm{5,} \mathrm{6,}$ dan 7. Kemudian dishaker selama 30 menit dengan kecepatan putaran $180 \mathrm{rpm}$. Setelah itu ditampung dan ditepatkan volumenya $10 \mathrm{~mL}$ dengan aquades $\mathrm{pH}$ yang sama, dan ditambah 1 tetes asam nitrat p.a dan diukur dengan SSA.

\section{d. Pengaruh Lama Pemanasan Terhadap Penyerapan Ion Logam $\mathrm{Cu}$ dan $\mathrm{Pb}$}

Ditimbang masing-masing 0,5 gram sekam padi dengan ukuran partikel $212 \mathrm{~m}$, lalu dipanaskan pada suhu $250{ }^{\circ} \mathrm{C}$ dengan variasi lama pemanasan: 1,$5 ; 2 ; 2,5$; dan 3 jam. Lalu ditambahkan larutan ion logam dengan konsentrasi $20 \mathrm{ppm}$. Kemudian dishaker selama 30 menit dengan kecepatan putaran $180 \mathrm{rpm}$. Setelah itu disaring, dan filtrat yang dihasilkan ditampung dan ditepatkan volumenya $10 \mathrm{~mL}$ dengan aquades. Lalu ditambah 1 tetes asam nitrat p.a. dan diukur dengan SSA.

\section{Aplikasi}

\section{a. Penyerapan Limbah Multikomponen}

Adsorben dengan ukuran partikel $212 \mathrm{~m}$ ditimbang masing-masing dengan berat 0.5 gram, lalu ditambahkan $10 \mathrm{~mL}$ larutan ion logam multikomponen (dengan konsentrasi dan pH pada kondisi optimum) Kemudian dishaker selama 30 menit dengan kecepatan putaran 180 rpm. Setelah itu ditampung dan ditepatkan volumenya $10 \mathrm{~mL}$ dengan aquadest yang kondisinya sama dengan larutan ion logam yang ditambahkan. lalu ditambahkan 1 tetes asam nitrat p.a dan diukur dengan SSA.

\section{b. Penyerapan Limbah PLT}

Adsorben dengan ukuran partikel $212 \mathrm{~m}$ ditimbang masing-masing dengan berat 0,5 gram, lalu ditambahkan $10 \mathrm{~mL}$ larutan ion logam yang berasal dari limbah PLT dengan $\mathrm{pH}$ yang telah diatur sesuai dengan kondisi optimum. Kemudian dishaker selama 30 menit dengan kecepatan putaran $180 \mathrm{rpm}$. Setelah itu ditampung dan ditepatkan volumenya $10 \mathrm{~mL}$ dengan aquadest yang kondisinya sama dengan larutan limbah yang ditambahkan. lalu ditambahkan 1 tetes asam nitrat p.a dan diukur dengan SSA.

\section{HASIL DAN PEMBAHASAN}

Adsorben dibuat melalui proses karbonisasi sekam padi dalam tungku pembakar furnace pada suhu $250{ }^{\circ} \mathrm{C}$. Besarnya suhu yang digunakan dalam penelitian ini berdasarkan hasil penelitian yang dilakukan oleh Seleng (1997). Pada penelitian Asyar et al., (1996) juga menunjukkan bahwa penggunaan suhu pada 
proses karbonisasi di atas $250{ }^{\circ} \mathrm{C}$ menyebabkan hasil adsorben yang didapat semakin sedikit. Hal ini disebabkan karena pada suhu rendah sebagian besar sekam padi terbakar menjadi karbon (arang). Sedangkan pada suhu yang lebih tinggi sebagian arang tersebut terbakar lebih lanjut sehingga berubah menjadi abu. Jadi, makin tinggi suhu pembakaran, maka semakin besar bagian sekam yang berubah menjadi abu. Oleh sebab itu berat arang hasil karbonisasi semakin berkurang.

Sebelum dilakukan karbonisasi, terlebih dahulu sekam padi dicuci dengan air bersih untuk membebaskan kotoran-kotoran yang mungkin menempel pada sekam padi. Setelah dicuci bersih, dilakukan proses pengeringan untuk mengeliminasi kandungan air dalam sekam padi dengan cara menguapkan air dari permukaan sekam padi. Proses pengeringan ini diikuti oleh pengurangan volume. Menuut Harsono (2002), laju pengeringan menurun seiring dengan penurunan kadar air selama penguapan dan berlangsungnya proses pengeringan tidak terjadi dalam suatu waktu sekaligus.

Setelah didapatkan arang sekam padi, maka arang tersebut diayak menggunakan ayakan berukuran $212 \mathrm{~m}$. Hal ini disebabkan karena efisiensi penyerapan adsorben terhadap adsorbat sangat dipengaruhi oleh ukuran partikel adsorben. Secara teoritis efisiensi penyerapan akan semakin meningkat dengan semakin kecilnya ukuran partikel. Hal ini disebabkan karena bertambahnya luas permukaan adsorben, sehingga ion-ion akan lebih banyak terserap pada permukaan biosorben tersebut (Sunarya, 2006).

Untuk melihat pengaruh variasi jumlah adsorben digunakan konsentrasi untuk masingmasing larutan ion logam sebesar 20 ppm. Dan variasi massa adsorben yang diujikan adalah 0,5 , 1.0, dan $1.5 \mathrm{~g}$. Adsorpsi dilakukan dalam sistem batch menggunakan shaker (pengguncang). Proses adsorpsi dilakukan pada suhu ruang, yaitu $26^{\circ} \mathrm{C}$. pemilihan suhu ruang ini karena proses adsorpsi pada suhu yang semakin tinggi menyebabkan ion logam berat yang terserap oleh adsorben semakin sedikit. Hal ini terjadi karena semakin tinggi suhu pada proses adsorpsi, maka pergerakan ion semakin cepat sehingga jumlah

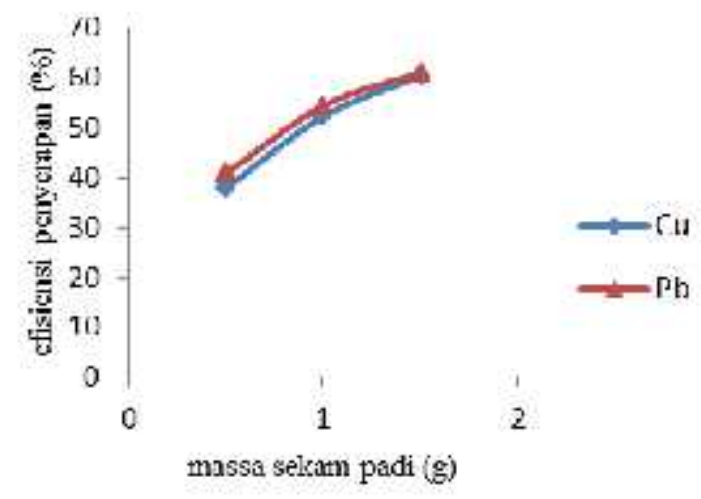

Gambar 1. Pengaruh Variasi Massa Sekam Padi Terhadap Ion Logam $\mathrm{Cu}$ dan $\mathrm{Pb}$

Ion logam berat yang terserap oleh adsorben semakin berkurang (Kundari dan Slamet, 2008). Penyerapan ion logam secara maksimum terjadi pada massa sekam padi $1.5 \mathrm{~g}$ dengan efisiensi penyerapan untuk ion logam berat $\mathrm{Cu}$ dan $\mathrm{Pb}$ masing-masing sebesar $60.37 \%$ dan $61.02 \%$ (gambar 1). Semakin besar massa sekam padi yang digunakan, maka efisiensi penyerapannya terhadap ion logam semakin besar. Bertambahnya berat sekam padi sebanding dengan bertambahnya jumLah partikel dan luas permukaan sekam padi sehingga menyebabkan jumlah tempat mengikat ion logam juga bertambah dan efisiensi penyerapan pun meningkat (Refilda, 2001).

Kemampuan penyerapan suatu adsorben dapat dipengaruhi oleh $\mathrm{pH}$ larutan. Hal ini berhubungan dengan protonasi atau deprotonasi permukaan sisi aktif dari sorben (Nurhasni, 2002). Menurut Riapanitra (2006), pH akan mempengaruhi muatan permukaan adsorben, derajat ionisasi dan spesi apa saja yang dapat terserap dalam adsorpsi tersebut. Nilai $\mathrm{pH}$ juga dapat mempengaruhi kesetimbangan kimia, baik pada adsorbat maupun pada adsorben. Dalam variasi $\mathrm{pH}$ ini kemungkinan ikatan kimia antara adsorben dengan adsorbat dapat terjadi (Refilda, 2001).

Dari gambar 2 terlihat bahwa penyerapan optimum adalah pada $\mathrm{pH}$ 6. Dengan nilai efisiensi penyerapan untuk ion logam $\mathrm{Cu}$ dan $\mathrm{Pb}$ masing-masing sebesar 98.52\%; 98.74\%.

Pada $\mathrm{pH}$ rendah penyerapan terhadap semua ion logam rendah. Hal ini dikarenakan pada $\mathrm{pH}$ rendah permukaan adsorben dikelilingi 


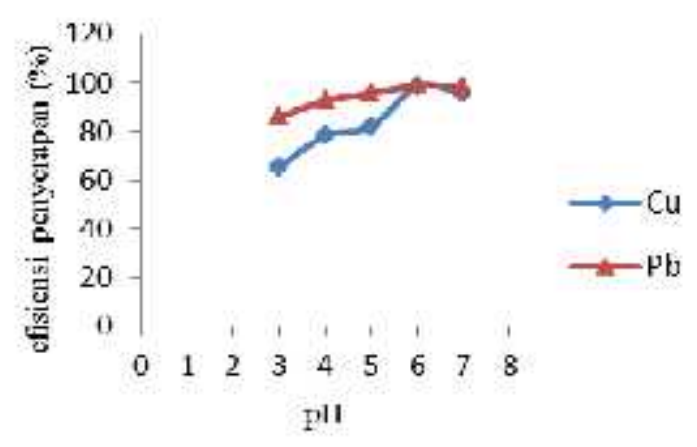

Gambar 2. Pengaruh $\mathrm{pH}$ Ion Logam $\mathrm{Cu}$ dan $\mathrm{Pb}$ Terhadap Efisiensi Penyerapan Sekam Padi

oleh ion $\mathrm{H}^{+}$(karena gugus fungsi yang terdapat pada adsorben terprotonasi). Dalam kondisi asam permukaan adsorben juga bermuatan positif, yang akan menyebabkan terjadi tolakan antara permukaan adsorben dengan ion logam, sehingga adsorpsinya pun menjadi rendah (Sembiring, 2009).

Pada $\mathrm{pH}$ netral efisiensi penyerapan juga menurun. Hal ini disebabkan karena pada $\mathrm{pH}$ netral ion-ion logam dapat mengalami reaksi hidrolisis dalam larutan sehingga ia tidak stabil dalam bentuk ion logam semula dan menyebabkan kemampuan sekam padi untuk menyerapnya menurun. Sedangkan pada $\mathrm{pH}$ basa, ion-ion logam dapat membentuk endapan hidroksida sehingga efisiensi penyerapannya sukar untuk ditentukan (Refilda et al., 2001; Utomo et al., 2006).

Volume larutan ion logam yang digunakan dalam penelitian ini sebanyak $10 \mathrm{~mL}$. Pemilihan volume ini didasarkan pada asumsi Refilda et al., (2001), yaitu jika digunakan jumLah ion logam yang lebih banyak akan menyebabkan permukaan sekam padi menjadi lebih cepat jenuh.

Gambar 3 menunjukkan konsentrasi ion logam terhadap efisiensi penyerapan sekam padi. Dari gambar tersebut terlihat bahwa kondisi optimum penyerapan dicapai pada konsentrasi 20 ppm, dengan efisiensi penyerapan untuk ion logam $\mathrm{Cu}$ dan $\mathrm{Pb}$ masingmasing sebesar $88.75 \%$ dan $93.79 \%$. Dengan meningkatnya konsentrasi ion logam, efisiensi penyerapan pun menjadi berkurang, dikarenakan kemampuan menyerap sekam padi terhadap ion

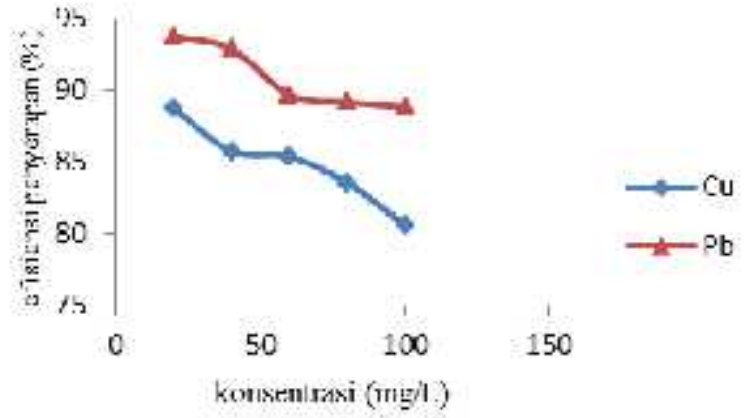

Gambar 3. Pengaruh Konsentrasi Ion Logam $\mathrm{Cu}$ dan $\mathrm{Pb}$ Terhadap Efisiensi Penyerapan Sekam Padi

logam berat $\mathrm{Cu}$ dan $\mathrm{Pb}$ sudah maksimum. Dengan kata lain kapasitas serap maksimum sekam padi telah tercapai pada konsentrasi 20 ppm (Kundari dan Slamet, 2008).

Menurut Refilda et al., (2001), penurunan efisiensi penyerapan disebabkan karena pada konsentrasi yang lebih tinggi, jumLah ion logam dalam larutan tidak sebanding dengan jumLah pertikel sekam padi yang tersedia sehingga permukaan sekam padi akan mencapai titik jenuh dan efisiensi penyerapan pun menjadi menurun.

Kedua pendapat tersebut sesuai dengan teori Langmuir yang menjelaskan bahwa pada permukaan adsorben terdapat situs aktif yang jumlahnya sebanding terhadap luas permukaan adsorben, sehingga bila situs aktif pada permukaan dinding sel adsorben telah jenuh oleh ion logam, maka penambahan konsentrasi tidak lagi dapat meningkatkan kemampuan adsorpsi dari adsorben tersebut. Oleh sebab itu, pada konsentrasi lebih dari 20 ppm, adsorpsi ion logam mengalami penurunan (Sembiring et al, 2008).

Menurut Wijayanti (2009) bila permukaan sudah jenuh atau mendekati jenuh terhadap adsorbat, dapat terjadi dua hal:

1. Terbentuk lapisan adsorpsi kedua dan seterusnya di atas adsorbat yang telah terikat di permukaan, gejala ini disebut adsorpsi multilayer.

2. Tidak terbentuk lapisan kedua dan seterusnya sehingga adsorbat yang belum teradsorpsi berdifusi keluar pori dan kembali ke arus fluida. 


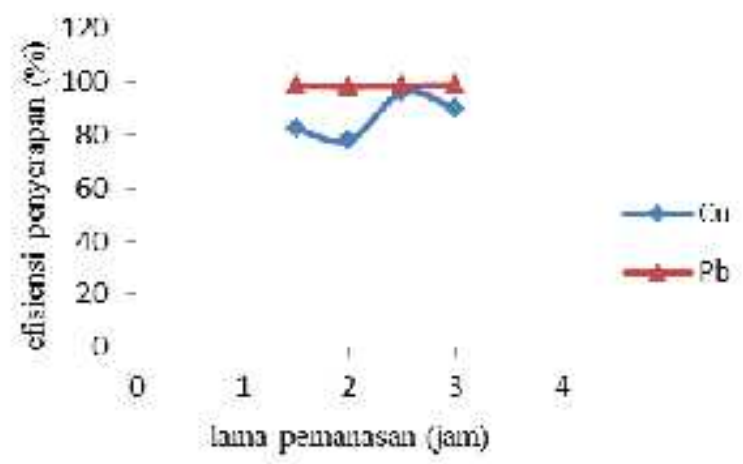

Gambar 4. Pengaruh Lama Pemanasan Sekam Padi Terhadap Penyerapan Ion Logam Cd dan Cr.

Pemanasan sorben dapat meningkatkan kemampuan penyerapan terhadap adsorbat. Pemanasan yang dilakukan dapat memperbesar pori-pori adsorben sehingga akan meningkatkan efisiensi penyerapan (Nurhasni, 2002).

Diketahui bahwa suhu karbonisasi berpengaruh terhadap keaktifan adsorben, semakin tinggi suhu makin rendah daya serapnya. Hasil penelitian menunjukkan karbonisasi sekam pada suhu di atas $250^{\circ} \mathrm{C}$ diperoleh adsorben dengan daya adsorpsi yang sangat rendah. Hal ini dapat dijelaskan karena pada suhu di atas $250^{\circ} \mathrm{C}$ sebagian besar sekam padi diubah menjadi abu sekam. Abu sekam banyak mengandung senyawa silika. Senyawa ini memiliki daya serap rendah dibandingkan karbon karena kurang pori pada permukaan partikel (Asyar et al., 1996).

Pada penelitian ini dilakukan proses karbonisasi pada suhu $250^{\circ} \mathrm{C}$ dengan variasi lamanya pemanasan. Dari gambar 4 terlihat bahwa kondisi optimum penyerapan sekam padi rata-rata dicapai pada pemanasan $250^{\circ} \mathrm{C}$ selama 2,5 jam. Sedangkan untuk pemanasan lebih lama lagi efisiensinya mulai menurun, hal ini disebabkan karena terjadinya perubahan struktur dari sekam padi tersebut.

Pengaruh interaksi larutan multikomponen dilakukan dengan tujuan untuk mengetahui kompetisi logam yang terserap pada permukaan sekam padi. Limbah multikomponen yang digunakan dibuat secara simulasi berdasarkan kondisi optimum yang didapat dari data penentuan kondisi optimum sebelumnya masing-masing ion logam. Dari tabel 1 terlihat bahwa penyerapan sekam padi terhadap larutan multikomponen memberikan efisiensi penyerapan yang sangat baik. Hal ini menunjukkan bahwa sekam padi dengan kondisi optimum yang diperoleh merupakan suatu adsorben yang sangat baik untuk digunakan sebagai bahan penyerap.

Nilai kapasitas penyerapan yang dihasilkan juga cukup baik. Kapasitas adsorpsi arang aktif bergantung pada karakteristik arang aktifnya, seperti: tekstur (luas permukaan, distribusi ukuran pori), kimia permukaan (gugus fungsi pada permukaan), dan kadar abu. Kondisi larutan juga berpengaruh, seperti: $\mathrm{pH}$, konsentrasi, dan adanya kemungkinan adsorpsi terhadap zat lain (Villacarias, 2005).

Tabel 1. Hasil Penyerapan Sekam Padi Terhadap Larutan Multikomponen

\begin{tabular}{cccc}
\hline No & Ion Logam & $\mathbf{E P}(\boldsymbol{\%})$ & $\mathbf{K P}(\mathbf{m g} / \mathbf{g})$ \\
\hline 1. & $\mathrm{Cu}$ & 82,16 & 0,3526 \\
2. & $\mathrm{~Pb}$ & 99,38 & 0,4702 \\
\hline
\end{tabular}

EP = Efisiensi Penyerapan

$\mathrm{KP}=$ Kapasitas Penyerapan

\section{Aplikasi}

Penyerapan sekam padi terhadap ion logam dalam air limbah Pusat Laboratorium Terpadu (PLT) Universitas Islam Negeri Syarif Hidayatullah Jakarta khususnya laboratorium kimia analitik, diperoleh kadar ion logam seperti terdapat dalam tabel 2 .

Tabel 2. Hasil Penyerapan Sekam Padi Terhadap Ion Logam dalam Air Limbah PLT UIN Syarif Hidayatullah Jakarta

\begin{tabular}{cccc}
\hline No & $\begin{array}{c}\text { Ion } \\
\text { Logam }\end{array}$ & $\begin{array}{c}\text { Efisiensi } \\
\text { Penyerapan } \\
(\%)\end{array}$ & $\begin{array}{c}\text { Kapasitas } \\
\text { Penyerapan } \\
(\mathbf{m g} / \mathbf{g})\end{array}$ \\
\hline 1. & $\mathrm{Cu}$ & 78,57 & $2,2 \times 10^{-3}$ \\
2. & $\mathrm{~Pb}$ & - & - \\
\hline
\end{tabular}




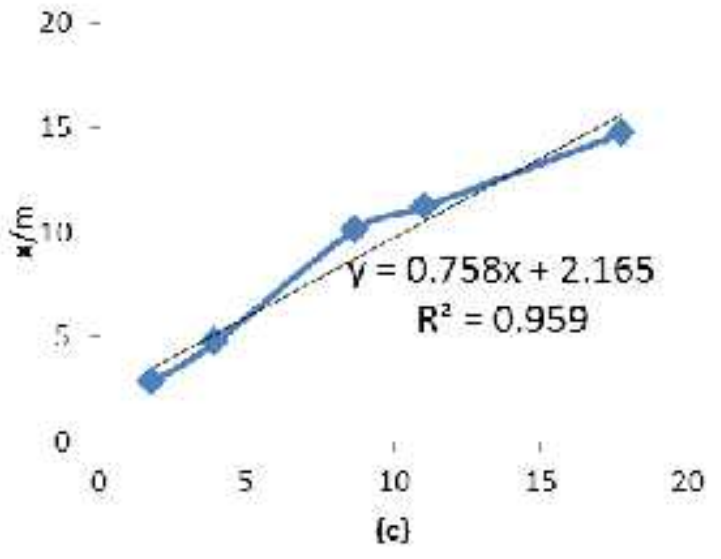

Gambar 5. Grafik Langmuir Logam Cu

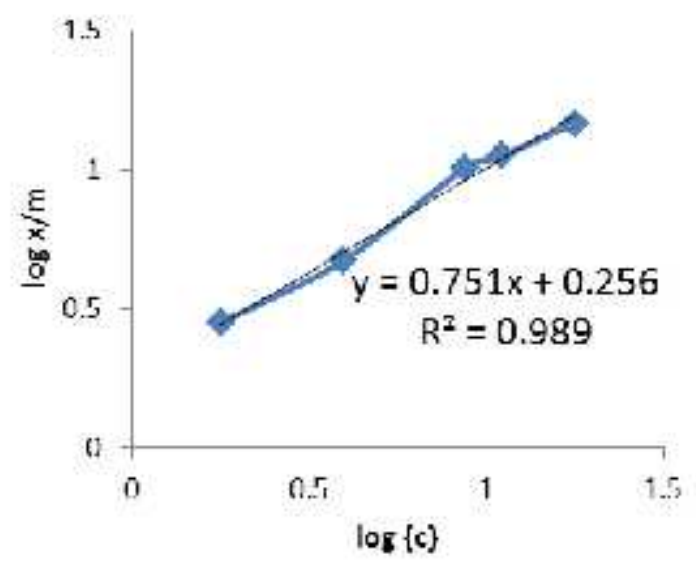

Gambar 6. Grafik Freundlich Logam Cu

\section{Isoterm Adsorpsi}

Isoterm Langmuir merupakan proses adsorpsi yang berlangsung secara kimisorpsi satu lapis. Menurut Langmuir dalam Amri (2004), pada permukaan adsorben terdapat situssitus aktif bersifat homogen yang proporsional dengan luas permukaan. Masing-masing situs aktif hanya dapat mengadsorpsi satu molekul adsorbat saja sehingga adsorpsi hanya akan terbatas pada pembentukan lapisan tunggal (monolayer), sedangkan isoterm freundlich merupakan proses adsorpsi yang terjadi secara fisisorpsi banyak lapisan.

Gambar 5 menunjukkan grafik isoterm Langmuir. Terlihat bahwa grafik yang diperoleh adalah grafik linier dengan persamaan $y=a+b x$, dengan nilai koefisien korelasi $\left(\mathrm{R}^{2}\right)$ mendekati 1 ,

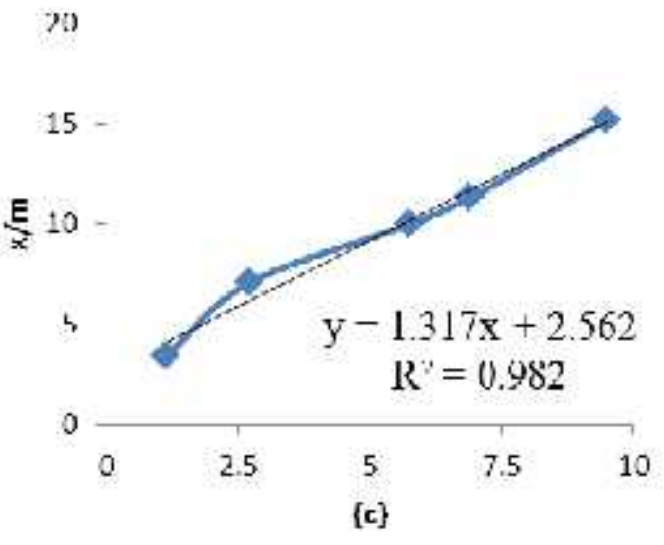

G

ambar 7. Grafik Langmuir Logam Pb

$$
1.3
$$

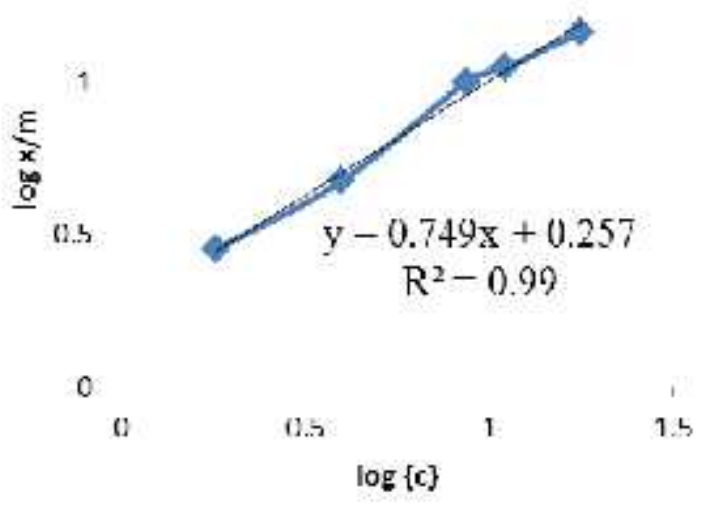

Gambar 8. Grafik Freundlich Logam Pb

sehingga dapat dikatakan bahwa data-data yang diperoleh dari penelitian ini sesuai dengan model kesetimbangan adsorpsi Langmuir.

Gambar 6 menunjukkan grafik isoterm Freundlich. Dari kedua grafik isoterm $\operatorname{logam} \mathrm{Cu}$, dapat dilihat bahwa perbandingan nilai koefisien korelasi $\left(\mathrm{R}^{2}\right)$ dari persamaan kesetimbangan adsorpsi Langmuir dan Freundlich mendekati 1, yaitu 0,959 untuk isotherm Langmuir dan 0,989 untuk isotherm Freundlich. Dari nilai $\mathrm{R}^{2}$ tersebut dapat diketahui model persamaan kesetimbangan mana yang dapat mewakili reaksi yang terjadi pada penelitian ini. Nilai $\mathrm{R}^{2}$ dari model freundlich lebih mendekati 1 dibandingkan model isoterm Langmuir. Hal ini menunjukkan bahwa data-data yang diperoleh lebih mengikuti model persamaan 
kesetimbangan adsorpsi Freundlich. Hal juga diperkuat oleh nilai energi adsorpsi, yakni $\mathrm{E}=$ $2.608 \mathrm{~kJ} / \mathrm{mol}$. Nilai adsorpsi ini diperoleh dengan cara mensubtitusikan nilai $\mathrm{K}$ (yang ditentukan dari grafik isoterm di atas) ke dalam persamaan $\mathrm{E}=-\mathrm{G}^{0}=\mathrm{RT} \ln \mathrm{K}$ (Sembiring et al., 2008).

Gambar 7 dan 8 menunjukkan grafik isoterm adsorpsi dari ion logam $\mathrm{Pb}$. Nilai koefisien korelasi $\left(\mathrm{R}^{2}\right)$ dari grafik isoterm Langmuir mendekati 1, yaitu 0.982 sedangkan nilai koefisien korelasi dari isoterm Freundlich sebesar 0.986. Hal ini menunjukkan bahwa datadata yang diperoleh dari penelitian ini tidak sesuai dengan model kesetimbangan adsorpsi Langmuir. Nilai energi adsorpsi yang di dapat adalah $\mathrm{E}=-1.656 \mathrm{~kJ} / \mathrm{mol}$. Nilai (-) menunjukkan bahwa proses biosorpsi berlangsung spontan dan bersifat eksoterm (Diantariani et al., 2008).

\section{SIMPULAN}

Dari penelitian yang telah dilakukan, yaitu mengenai adsorpsi menggunakan sekam padi dapat ditarik beberapa kesimpulan. Diantaranya adalah:

1. Kondisi optimum untuk ion logam $\mathrm{Cu}$ dan $\mathrm{Pb}$ dengan parameter massa adsorben $0.5 \mathrm{~g}$; konsentrasi larutan ion logam 20 ppm, pH 6 serta lama pemanasan selama 2.5 jam untuk $\mathrm{Cu}$ dan 3 jam untuk $\mathrm{Pb}$.

2. Pada larutan multikomponen nilai efisiensi penyerapan yang paling tinggi adalah logamPb,yaitu sebesar $99.38 \%$ dengan nilai kapasitas penyerapan sebesar $0.4703 \mathrm{mg} / \mathrm{g}$; sedangkan pada limbah nilai efisiensi penyerapan yang paling tinggi adalah pada logamCu,yaitu7 sebesar $78.57 \%$ dengan nilai kapasitas penyerapan sebesar $0.0213 \mathrm{mg} / \mathrm{g}$.

3. Adsorpsi terhadap ion logam $\mathrm{Cu}$ dan $\mathrm{Pb}$ berlangsung secara fisisorpsi dengan linieritas mencapai $90 \%$ untuk tipe isoterm Freundlich.

\section{UCAPAN TERIMA KASIH}

Pada kesempatan ini penulis mengucapkan terima kasih kepada Dr. Mirzan T Razzak, M.Eng.,APU selaku Direktur Pusat Laboratorium Terpadu UIN Syarif Hidayatullah Jakarta yang telah member izin untuk melaksanakan penelitian ini, dan staff Laboratorium Kimia atas segala do'a dan dukungannya.

\section{DAFTAR PUSTAKA}

Amri, A., Supranto dan Fahrurozi, M., 2004, Kesetimbangan Adsorpsi Optimal Campuran Biner $\mathrm{Cd}$ (II) dan $\mathrm{Cr}$ (III) dengan Zeolit Alam Terinpregnasi 2merkaptobenzotiazol. Jurnal Natur Indonesia., 6(2): 111-117.

Asyar, Rayandra., M. Saleh Arif., M. Rusdi., 1996, Diversifikasi Pemanfaatan Padi Sebagai Adsorben $\beta$-karoten pada Pemurnian Minyak Sawit Mentah. Skripsi., Jambi: Universitas Jambi.

Collen, K., R.E. Mielke., D. Dimaquibo., A.J. Curtis., and J.G. Dewitt, 1999, Adsorption of Eu (III) onto Roots of Water Hyacinth. J. Environ. Sci. Technol., (33): 14391443

Danarto, 2007, Adsorpsi Limbah Logam Berat Multikomponen dengan Karbon dari Sekam Padi, Skripsi., Surakarta: Universitas Sebelas Maret.

Diantariani, N.P., I.W. Sudiarta, dan N.K. Elantiani, 2008, Proses Biosorpsi dan Desorpsi ion Cr (VI) pada Biosorben Rumput Laut Eucheuma spinosum, J. Kimia., Denpasar: Jurusan Kimia FMIPA Universitas Udayana.

Harsono, Heru., 2002, Pembuatan Silika Amorf dari Limbah Sekam Padi, Jurnal Ilmu Dasar., 2(3): 98-103.

Jalali, R., Ghafurian, H., Davarpanah, S.J., and Sepehr, S., 2002, Removal and Recovery of Lead Using Non Living Biomass of Marine Algae, Journal of Hazardous Material B92., 253-262.

Kundari, N.A., dan Slamet, Wiyuniati., 2008, Tinjauan Kesetimbangan Adsorpsi Tembaga dalam Limbah Pencuci PCB dengan Zeolit, Yogyakarta: Seminar Nasional IV SDM Teknologi Nuklir.

Lembang, J., T. Sakka., A.M. Nurbakti, (1995), Rekayasa dan Pembuatan Tungku Pembakar Sekam Padi untuk Pembuatan Arang Aktif dari Sekam Padi, Ujung Pandang: Balai Industri Ujung pandang. 
Low, K.S., C.K. Lee, and S.G. Tan, 1995, Effect of Dye Modification on the Sorption of Copper by Coconut Husk. J. Environ. Tech., (16): 877-883.

Low, K.S., C.K. Lee, and S.G. Tan, 1997, Sorption of Trivalent Chromium from Tannery Waste by Moss. J. Environ. Tech., (18): 449-454.

Maranon, E., and H. Saetre,1991, Heavy Metal Removal in Packed Bed Using Apple Waste. Anal. Chem., (64): 39-44.

Nurhasni, 2002, Penggunaan Genjer (Limnocharis Flava) Untuk Menyerap Ion Kadmium, Kromium, dan Tembaga Dalam air Limbah, Tesis., Padang: Universitas Andalas.

Riapanitra, Anung., T. Setyaningtyas dan K. Riyani. 2006. Penentuan Waktu Kontak dan pH Optimum Penyerapan Metilen Biru Menggunakan Abu Sekam Padi. J. Molekul. 1(1): 41-44.

Refilda., Rahmiana Zein., Rahmayeni, 2001, Pemanfaatan Ampas Tebu Sebagai Bahan Alternatif Pengganti Penyerap Sintetik Logam-logam Berat Pada Air Limbah, Skripsi., Padang: Universitas Andalas.

Seleng, Tarcisius dan Tallu Lembang. 1997. Pengaruh Perendaman Bahan Baku Dalam Larutan $\mathrm{NaOH}$ Terhadap Daya Serap Karbon Aktif Dari Sekam Padi. Majalah Kimia (57): 15-18.

Sembiring, Zipora., Suharso., Regina., Faradila Marta dan Murniyarti. 2008. Studi Proses Adsorpsi-Desorpsi Ion Logam $\mathrm{Pb}$ (II), $\mathrm{Cu}(\mathrm{II})$, dan $\mathrm{Cd}(\mathrm{II})$ Terhadap Pengaruh Waktu dan Konsentrasi pada Biomassa "Nannochloropsis, sp" yang Terenkapsulasi Aqua-Gel Silika dengan Metode Kontinyu. Prosiding. Seminar Nasional Sains dan Teknologi-II., Bandar Lampung: Universitas Lampung.
Sembiring, Zipora., Buhani., Suharso., dan Sumadi, 2009, Isoterm Adsorpsi Ion $\mathrm{Pb}(\mathrm{II}), \mathrm{Cu}(\mathrm{II})$, dan $\mathrm{Cd}$ (II) pada Biomassa Nannochloropsis, $s p$ yang Dienkapsulasi Akuagel Silika. Indo. J. Chem., 9(1): 1-5.

Setyaningtyas, Tien., Zusfahair., dan Suyata, 2005, Pemanfaatan Abu Sekam Padi Sebagai Adsorben Kadmium (II) dalam Pelarut Air. Majalah Kimia Universitas Jenderal Soedirman., 31(1): 33-41.

Shengjun, $M$ and Holcombe J.A., 1990, Preconcentration of Copper on Algae and Determination By Slurry Furnace Atomic Absorption Spectrometry. Anal. Chem., (62): 1994-1997.

Sunarya, Asri Ismayati., 2006, Biosorpsi Cd (II) dan $\mathrm{Pb}$ (II) Menggunakan Kulit Jeruk Siam (Citrus reticulata). Skripsi., Bogor: Institut Pertanian Bogor.

Utomo, H.D., and K.A. Hunter, 2006, Adsorption of Heavy Metal by Exhausted Coffee Grounds as a Potential Treatment Method for Waste Waters. e-J. Surf. Sci. Nanotech., (4): 504-506.

Villacarias, F., 2005, Adsorption of Simple Aromatic Compound on Activated Carbon, J. of Colloid and Interface Science., (293): 128-136.

Wijayanti, Ria., 2009, Arang Aktif dari Ampas Tebu Sebagai Adsorben pada Pemurnian Minyak Goreng Bekas. Skripsi., Bogor: Institut Pertanian Bogor.

Wiloso, E.I., A.H. Setiawan dan V. Barlianti, 2003, Penyerapan Zat Warna Basic Red 18 dalam Kolom dengan Menggunakan Media Dedak. Majalah Dasar-dasar Teknik Kimia, Prosiding., Puspitek: Pusat Penelitian Kimia- Lembaga Ilmu Pengetahuan Indonesia. 